Article

\title{
The Institutionalization of the Consistency and Comparability Principle in the European Companies
}

\author{
Viorel Avram, Daniela Artemisa Calu *, Valentin Florentin Dumitru, Mădălina Dumitru®, \\ Mariana Elena Glăvan and Gabriel Jinga \\ Faculty of Accounting and Management Information Systems, The Bucharest University of Economic Studies, \\ Bucharest 014576, Romania; viorel.avram@cig.ase.ro (V.A.); valentin.dumitru@cig.ase.ro (V.F.D.); \\ madalina.dumitru@cig.ase.ro (M.D.); elena.glavan@cig.ase.ro (M.E.G.); gabriel.jinga@cig.ase.ro (G.J.) \\ * Correspondence: daniela.calu@cig.ase.ro; Tel.: +40-726-373-003
}

Received: 13 November 2018; Accepted: 7 December 2018; Published: 10 December 2018

\begin{abstract}
There is a general tendency in reporting nowadays, represented by the institutionalization of the environmental reporting in an increasing number of companies. The novelty of our work resides in the fact that this is the first study which analyses the consistency and comparability of the information included in integrated reports. The objective of this research is to determine to what extent the reporting of the environmental performance indicators, including energy, prescribed by the Global Reporting Initiative's guidelines is in line with the consistency and comparability principle. We analysed the reports published by the European organisations included in the Pilot Programme of the International Integrated Reporting Council. We used the following methodology. First, we compared the environmental reporting of 2016 from one company to another, splitting the sample in accordance with the industries. Second, we analysed the reporting practices of the environmentally-sensitive companies, including energy, in 2010, 2013 and 2016, in order to analyse the consistency of the information published. The results of the research show that the environmentally-sensitive companies, including energy, publish more information. Also, the score of information consistency is above average. The best consistency level is registered in the Basic Materials industry, followed by Oil \& Gas and Industrials. Emissions and energy indicators are the most disclosed. This research is useful to understand how companies apply the consistency and comparability principle in practice. The importance of this article is given by the fact that consistency and comparability improve the quality of the sustainability reporting. Without consistency and comparability the information's relevance is very low.
\end{abstract}

Keywords: consistency; comparability; environmental performance indicators; Europe; energy; Global Reporting Initiative

\section{Introduction}

Measuring the environmental performance is a difficult attempt. Comparing the environmental performance from one company to another is even harder [1,2]. According to [3] (p. 3) 'non-financial performance plays a pivotal role in the investment decisions for most of the surveyed investors and for a greater percentage of the investors than in previous years'. At present the environmental reporting is an important concern for most of the companies, being often a distinction factor for competing entities. Recent studies have shown the benefits of the environmental reporting: better reputation [3-6], meeting the expectations of employees [6,7], improved access to capital [6,8,9], increased efficiency $[3,6]$, waste reduction $[6,10]$ and competitive advantages $[11,12]$. Even if the environmental reporting is voluntary in most of the world's countries, the number of companies reporting non-financial information related to the environment has significantly increased in the last years. Therefore, as a comparison, according 
to two studies [13,14] investigating in 1999 and 2017 the sustainability reports published by 250 companies included in the G250 35\% of the companies disclosed information on social, environmental and economic issues (commonly referred to as corporate social responsibility-CSR) in 1999 and $93 \%$ in 2017.

As there are almost 400 reporting instruments in place [15], a major issue which appears regarding the environmental reporting is the consistency and comparability of the information. The most comprehensive and used guidelines in the area are the ones issued by the Global Reporting Initiative (GRI) [14]. Thus, the objective of our research is to analyse the consistency and comparability of environmental performance indicators (EPIs), especially the ones related with energy and emissions issues, published by the European companies included in the International Integrated Reporting Council's (IIRC) Pilot Program using the GRI guidelines. Consistency assesses that the information is constantly disclosed in time while the comparability evaluates the disclosure of the information from one company to another. By analysing all the EPIs as opposed to only the ones related with energy and emissions, we emphasize better the importance of these categories of ratios. Also, the energy and emissions reporting is better presented in a context.

First, in order to assess the comparability we analyse the GRI indicators disclosed in 2016 by all the European companies included in the IIRC's PP. We split the sample into environmentallysensitive (including energy companies) versus non-sensitive companies and compared the indicators disclosed. For the selection of the environmentally-sensitive industries, we used the classification established by [16]: energy, metal mining, coal and lignite mining, oil exploration, paper, chemical and allied products, petroleum refining, glass, metals and air transportation. Second, in order to assess the consistency, we compared the information disclosed by the organizations involved in environmentally-sensitive industries, in the context of the changes in the environmental reporting. In order to do this, we determined a score of information consistency for each organization. We analysed the data published in 2010, 2013 and 2016. We chose the year 2010 as it is the year in which the IIRC was created. So, we consider it as a starting point for this research. We chose the year 2013 as it was the year in which the first integrated reports designed according to the International Integrated Reporting Framework (IIRF) were published. Finally, we chose the year 2016 as it is the last year for which published reports are available. We limited our research to the analysis of the consistency for the companies operating in sensitive industries because they are more likely to present environmental information [16].

The novelty of our work resides in the fact that this is the first study which analyses the consistency and comparability of the information included in integrated reports. We analysed these two concepts from multiple points of view: comparability from one company to another, consistency of the EPIs disclosed, consistency with targets, consistency with the information presented in previous reports. We enlarge the traditional focus of the literature on the comparability. We combined the concept of consistency with the concept of comparability because they are strictly related to each other. Also, our research method allows us to investigate the absence of the consistency and comparability (for instance, for certain EPIs) not only the presence. We adopted the institutional theory as a methodological framework (which is less used for the study of CSR reporting than the stakeholders and legitimacy theories) because it allows us to analyse the results using many characteristics of the sample. Thus, we focus on internal and external variables affecting the consistency and comparability. Finally, we commented on the policy implications of the consistency and comparability.

The paper is structured as it follows: first, we present a literature review. The paper continues with the research method. After the presentation of the results, we discuss our findings. The paper ends with the conclusions of the study. 


\section{Literature Review}

\subsection{The Consistency and Comparability of Environmental Reporting}

The conventional business model was focused on financial results and on investors as the main stakeholders. Over the past few years, the focus has shifted towards long-term values and various stakeholders [16-19]. In order to communicate information to stakeholders, organizations may use annual reports, CSR reports or integrated reports, as well as press releases, company brochures and other media channels [20]. The annual report influences significantly the way in which the market and stakeholders see and react to an organization [21]. If the information in the published reports is not able to influence both the behaviour of the organization that publishes that information and the stakeholders, the value of the information published in the reports is low ([22], p. 9).

At the international level there is a need to compare, measure, and rank companies from the sustainability's point of view [23-26]. Even though investors search for reliable 'ways to meaningfully compare companies' data, to understand which issues are most material to their sustainable growth and to draw quantifiable links between non-financial and financial performance' ([27], p. 1), they frequently assess the environmental performance 'on an informal, not structured basis' ([3], p. 3). The main difficulty in performing analyses in respect of the environmental reporting and implicitly the environmental performance consists in the limited consistency and comparability of the published information in the sustainability reports [13,28-30]. Given the fact that the information published in the sustainability reports has a high degree of heterogeneousness, the comparability between organizations is limited. The users are in a difficult situation because they do not know how companies compare to others [31]. Also, as the guidelines are numerous and their application is voluntary in most of the cases, the dynamics of change of the information displayed in the reports is an accelerated one. This aspect negatively affects the consistency of the information. The main difficulty to ensure the consistency and comparability of information comes from the fact that the type and quality of information disclosed is not homogeneous [32]. At the same time, the process of data collection and information management can vary in time or from one company to another [33]. Reference [1] pointed out 'the main causes of measurability and comparability problems: unclear, ambiguous, or incomplete answers, release of qualitative and non-comparable data, unspecific information, heterogeneous measurement units, report complexity and opacity, overemphasis on positive elements, and so forth.'

Despite of all difficulties, there is an implicit assumption that non-financial performance, including energy and emissions, can be measured and compared using different methodologies and tools [34-36]. One way to improve the consistency and comparability of information is the standardization of the environmental reporting [37]. This can be achieved within industries [37-40]. For this reason, we can see that the most of the studies that investigated the consistency and comparability of environmental indicators presented in non-financial reports did so by selecting companies within the same industrial sector such as [41-43].

Establishing the GRI in 1997 was a first important step in setting up a framework of voluntary reporting appropriate for all types of companies with focus on the economic, social and environmental dimensions related to their specific activities. This body developed in 2000 the first global framework for comprehensive sustainability reporting. Later on, GRI published several versions of specific Guidelines (G). The existing versions have been the following in time: G1 (2000), G2 (2002), G3.0 (2006), G3.1 (2011), G4 (2013). Further, in 2016 GRI published a set of GRI Sustainability Reporting Standards (SRS). The GRI guidelines were the most used with a share of about $89 \%$ of the corporate responsibility reports issued in 2016 by the G250 companies and 74\% in the case of the N100 companies [14]. Article [44] underlines that GRI has been successful in presenting a voluntary alternative to sustainable reporting but still retains a number of unresolved issues, mainly because of prioritization of the orientation to stakeholders.

Another action to develop the environmental reporting was the setup of a mixed professional body in 2010, the IIRC. It developed an IIRF, on the grounds of which the companies can publish 
integrated reports connecting both financial and non-financial information. Given the fact that there are not supplied key performance indicators at the level of the IIRF, IIRC encourages the organizations to use the GRI Sustainability Reporting Guidelines (with the related indicators) [45].

In the European Union, the first sustainability reporting program was the Eco-Management and Audit Scheme (EMAS) implemented in 1995. In time, the CSR reporting in Europe evolved from a recommendation to a combination of voluntary and mandatory reporting institutionalized in the large European undertakings by the ED 2014/95/EU regarding 'the disclosure of non-financial and diversity information by certain large undertakings and groups.' The information should be disclosed in a non-financial statement and reports. The disclosures are grouped in business model, environment, social and employee issues, respect for human rights, corruption and bribery, risks and risk management, and non-financial key performance indicators. Companies may use various frameworks, including the GRI guidelines. The Directive was first used for the reports prepared for 2017 and published in 2018. One of the purposes for enacting the Directive was to 'enhance the consistency and comparability of the non-financial information disclosed [46]. Preliminary research [47] argues that this purpose will be hard to be achieved because of the differences which arise at the transposition of the directive in the national legislation and because of the variate range of options available for reporting (for instance, a multitude of frameworks, unclear assurance requirements). It has been shown that even in experienced countries from the point of view of CSR reporting, the use of the Directive will represent an improvement $[48,49]$.

One of the principles which are included both in GRI guidelines and IIRF is the comparability principle. According to ([50], p. 23) consistency and comparability are defined as it follows: 'The information in an integrated report should be presented:

- On a basis that is consistent over time

- In a way that enables comparison with other organizations to the extent it is material to the organization's own ability to create value over time.'

According to GRI, 'The organization should select, compile and report information consistently. The reported information should be presented in a manner that enables stakeholders to analyse changes in the organization's performance over time, and that could support analysis relative to other organizations' ([51], p. 18).

GRI also explains that 'Comparability is necessary for evaluating performance. Stakeholders using the report should be able to compare information reported on economic, environmental and social performance against the organization's past performance, its objectives, and, to the degree possible, against the performance of other organizations' ([51], p. 18).

We understand thus that the comparability involves three dimensions:

(a) Comparability with the performance disclosed in the previous periods. In order to achieve this, the company should present the same indicators and use the same methodology in order to compute the indicators. Also, the values of the indicators presented in a year should not be changed in the next year's report for the base year;

(b) Comparability with the objectives involves the presentation of the objectives and the discussion in the next year of the way in which the objectives were reached;

(c) Comparability with other organizations only if this is possible, as everybody acknowledges that it is difficult to compare the incomparable, especially if we talk about companies in different activity domains.

\subsection{Policy Actions and Private Initiatives Regarding the Energy and Emissions}

Started as a need to replace the extinguishing fossil fuels, the renewable energy (RE) became an opportunity not only from the point of view of the sustainability, but also from the economic and social point of view. The energy is needed for any human activity and its use is still generating the highest part of greenhouse gas (GHG) emissions worldwide (about two-thirds) and it is the biggest 
source of air pollution [52]. Thus, the type of energy used (fossil or renewable) and its efficiency are linked with the environment [53]. The main RE sources are: hydropower, bio-power, geothermal, solar photovoltaics, wind. All the countries implemented policies to increase the share of the RE and, implicitly, to reduce the emissions. Policies can take the following forms: targets, feed-in policies, quota policies, tendering/public, competitive bidding, heat obligation/mandate, biofuel mandates [54]. Policies are directed towards electricity, heating and cooling, transport. The most effective RE policy actions are the feed-in policies and the quota policies for the green certificates [55,56], cooperation and public procurement [57].

Europe produces $5.6 \%$ of the total energy in the world, but it uses $11.9 \%$ of the energy in the world, generating $10.2 \%$ of the planetary $\mathrm{CO}_{2}$ emissions (https: / / www.energy.eu/publications/EUenergy-in-figures.pdf). In order to address the energy and emissions issues, EU adopted the targets presented in Table 1.

Table 1. Policy targets regarding the energy and emission issue.

\begin{tabular}{lcc}
\hline \multicolumn{1}{c}{ Items } & $\begin{array}{c}\mathbf{2 0 2 0} \\
\text { (Established in 2007) }\end{array}$ & $\begin{array}{c}\text { 2030 } \\
\text { (Established in 2014) }\end{array}$ \\
\hline Reduction in GHG emissions (base year: 1990) & $20 \%$ & $40 \%$ \\
Energy obtained from renewable sources & $20 \%$ & $27 \%$ \\
Improvement in energy efficiency & $20 \%$ & $27 \%$ \\
\hline
\end{tabular}

Source: authors' compilation.

The achievement of the targets will be possible with considerable costs regarding, for instance, research and innovation. Previous research showed that in Europe the costs are smaller than the benefits for hydropower and wind, but are higher for the other RE sources [58].

The RE policies are not the only ones which have an impact on the emissions. It has been shown that the economic reforms which generate emissions' reduction are the corporate governance and the competition policy [59]. However, a decrease in investments and subsidies from the EU leads to a reduction of the progress made by RE [60].

As a result of the efforts in the domains of energy and emissions, the last years registered flat $\mathrm{CO}_{2}$ emissions from fossil fuels and industry [58], increase in bio-heat and jobs in the domain [54].

The improvement in energy efficiency can bring multiple benefits which were grouped by [61] as presented in Figure 1.

In the assessment of the environmental and energetic performance of European countries, Sweden ranks first [62]. In terms of investment in renewable power and fuels and in solar PV capacity UK is the first European country [54]. The value of the annual investment in wind power is the highest in Germany [54]. Germany has the biggest RE capacity.

The following GRI indicators should be reported by the companies in order to keep track of the progress made to reach the EU targets: G4-EN3, G4-EN4, G4-EN6, G4-EN15, G4-EN17, G4-EN20, G4-EN21. Yet, the EU's energy targets do not take into account "inefficient land use, low water quality and availability, waste, air pollution, and losses of ecosystem services, fish stocks and biodiversity" [63]. In order to advance in respect of the sustainability issues, all the EPIs are important. Thus, in our research, we will focus on all of them as opposed to considering only the energy and emissions indicators. 


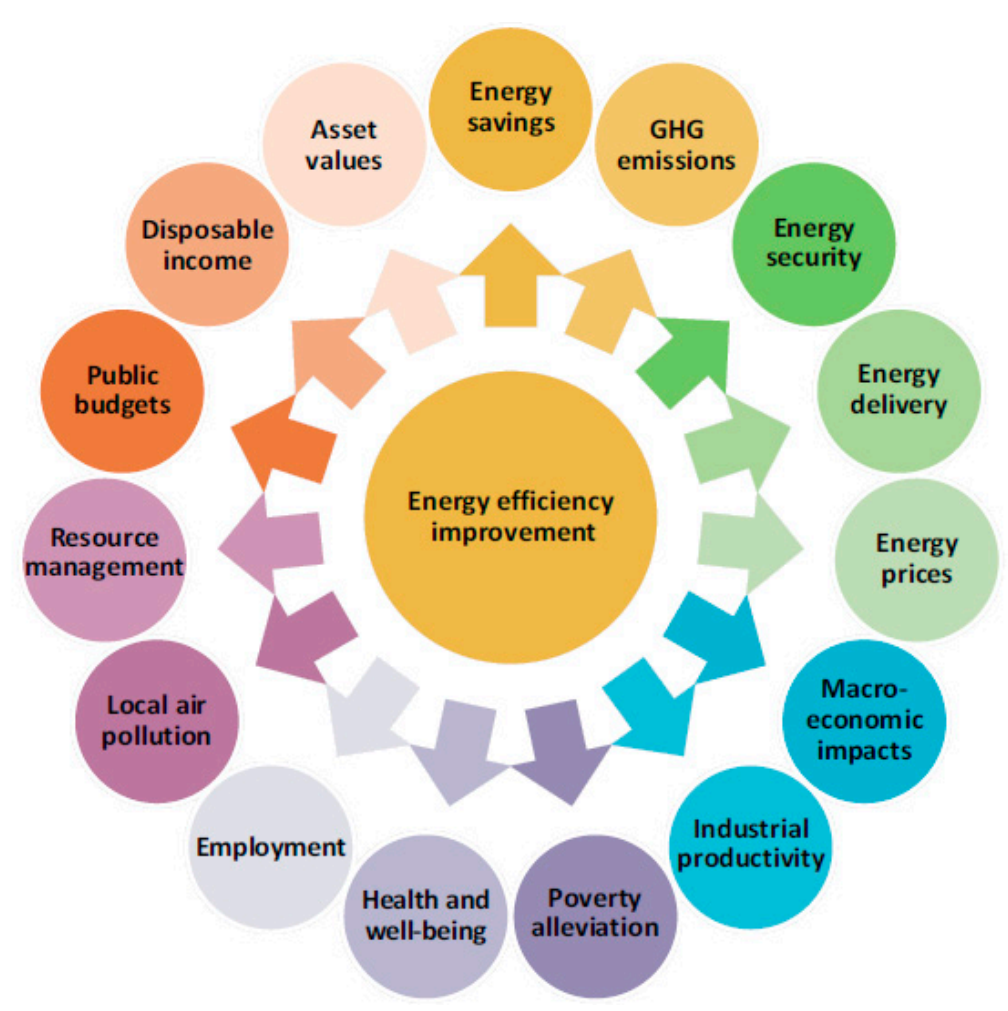

Figure 1. The benefits generated by the improvements in energy efficiency (IEA, 2014).

\section{Research Method}

Our research methodology can be briefly presented as it follows. In order to assess the comparability of the reports we assigned the score 1 if one indicator was disclosed in the reports and 0 if the indicator was not included. In order to assess the consistency of the reports we selected 18 indicators (Appendix B). We assigned the score 0 if the indicator was not presented at all, 1 point for the homogeneous disclosure of an indicator in all three years, 2 points for the homogeneous disclosure of the same indicator in two of the three years under examination, respectively 3 points for the different disclosure of an indicator in each of the three years. We applied the institutional theory. We tested the effect of the institutionalization of the GRI, integrated reporting, Global Compact, ISO 14001 and ISO 9001 on the comparability.

\subsection{Sample Selection}

The collection of information took place from 1 July to 31 December 2017. We started from the 99 international organizations which were included in the IIRC's PP. According to [11,64] inter-company comparability in sustainability reports doesn't exist for the companies situated in different geographical areas. Consequently, we extracted for our analysis the companies based in Europe. This selection provides homogeneous reports because of the existing EU laws and regulations. Also, Europe is the most active region in the world in terms of CSR reporting [64], and thus it represents an interesting research setting. 49 companies resulted. Ten companies are involved in environmentally-sensitive domains. The sample is presented in Table 2 and Appendix A. 
Table 2. Sample description.

\begin{tabular}{lccc}
\hline \multicolumn{1}{c}{ Description } & Total & Sensitive Companies & Non-Sensitive Companies \\
\hline Total number of companies & 49 & 10 & 39 \\
Companies applying GRI guidelines, of which: & 35 & 10 & 25 \\
- Applying G4 & 28 & 8 & 20 \\
- Applying SRS & 6 & 2 & 1 \\
- Citing GRI & 1 & 0 & 39 \\
Total number of reports analysed & 69 & (three investigated years) & (one investigated year) \\
\hline
\end{tabular}

Source: the authors' compilation.

\subsection{Data Collection}

We used content analysis in our research. Content analysis is defined as 'a research technique for making replicable and valid inferences from texts (or other meaningful matter) to the contexts of their use' [65], p. 18. We adopted a semi-objective approach, as we prepared ex ante a list of items and searched for their presence in the text. The approach is used by a large body of literature in the domain. We read the reports entirely and extracted the environmental indicators from the GRI guidelines (versions G3.0 [66], G3.1 [67], G4 [51,68], SRS [69]) applied by the organizations. The data regarding the provision of the environmental information was coded by two members of the research team. The results were discussed and reconciled.

The first part of our analysis consisted in identifying which EPIs included in the GRI guidelines were reported by the companies in 2016. We chose the GRI guidelines as they are the most used for environmental reporting at a global level. Also, they were applied along the entire research period. We extracted the data for the year 2016 from all the type of reports (annual reports, integrated reports, CSR reports, GRI content index etc.). We selected all the 34 environmental indicators that could have been reported by the organizations during the analysed period, in order to better emphasize the importance granted by the companies to the energy and emissions indicators. We coded the data using a dichotomous coding system as it follows:

- $\quad$ 1: if the EPI was reported;

- $\quad 0$ : if the EPI was not reported.

The maximum score which could have been assigned to one company was 34 . We compared the information disclosed by the environmentally-sensitive companies with the one disclosed by the other companies. We also compared the results obtained for the energy and emissions indicators with the other indicators.

We used NVivo Pro (QSR International Pty Ltd., Melbourne, VIC, Australia) to extract the most used words related with the EPIs reporting.

The second step of our analysis consists in assessing the consistency of the information disclosed in the reports published in 2010, 2013 and 2016. We analysed the consistency of environmental reporting for the sensitive industries. We selected 18 quantitative indicators (Appendix B) that could have been reported by the companies in the three years. Out of them, five indicators are related with the energy and emissions reporting. We applied the following selection criteria (C):

- $\quad \mathrm{C} 1$ : the indicator had to be quantitative (expressed by absolute or relative measures);

- C2: the indicator had to be included in all the versions of the GRI references applicable.

Thirty reports published in the three investigated years are analysed in total for ten organizations in six countries. The objective is to determine a score of quantitative EPI consistency for the three examined years. The score was granted as it follows:

- 1 point for the homogeneous disclosure of an indicator in all three years;

- 2 points for the homogeneous disclosure of the same indicator in two of the three years under examination, respectively 
- 3 points for the different disclosure of an indicator in each of the three years.

If an organization does not report an indicator, the value 0 is allocated to that specific indicator and that indicator was not taken into account. The sum of the scores obtained for the indicators reported by an organization is divided by the total number of the indicators reported by that specific organization in any of the three years analysed. The average score may range from 1 to 3, 1 representing the best value obtained for the information consistency score.

The purpose of this analysis is to identify an association between the change of the GRI guidelines and the change of the consistency of the indicators. Also, we wanted to identify differences between the number and the consistency and comparability of the reported indicators, according to the type of industry in which an organization is included.

Taking into account GRI requirements regarding the consistency and comparability principle, our analysis covered as well the consistency with past performance and the consistency with the objectives set by the companies.

\subsection{Institutional Theory}

In order to conduct this research, we applied the institutional theory. Institutional theory concerns the forms adopted by organizations and tries to explain why organizations are becoming more homogeneous within an organizational field [70]. Institutional theory provides "a powerful lens for helping to explain how we come to understand and accept different attitudes and practices in a particular social context" [71]. In our case, the institutional theory is used to explain the consistency and comparability of the EPIs reported by the selected companies. It was previously used in CSR reporting studies [72,73]. One of the dimensions of the institutional theory is the isomorphism. There are three types of isomorphism. The coercive isomorphism refers to the influence of the laws and regulations on homogenizing the practices. The normative isomorphism refers to the influence of the profession. The mimetic isomorphism occurs when organizations imitate others in the same field in order to increase their legitimacy [74].

There are countries (such as Denmark or France) in which the environmental regulations are mandatory. In this case, we expect to find evidence of coercive isomorphism. We assume that the implementation of the ED 2014/95 will lead to normative isomorphism. Also, by selecting several companies in the same domain, we consider that we will find examples of mimetic isomorphism.

The variables which can have an influence on the institutionalization of the consistency and comparability principle (as part of the environmental reporting) are: the impact of the industry on the environment (environmentally-sensitive industry or not); participation in CSR networks (for instance, member of the IIRC's PP, member of the United Nations Global Compact, member of a sustainability index included in the Stock Exchange); adoption of voluntary reporting standards (such as the GRI); country of origin; source of capital (public or private); stock exchange listing; size of the company (expressed, for instance, in terms of turnover, leverage, value of total assets, number of employees); auditor (Big 4 or another auditor); the date of European Union accession; religion; legal environment (principles or rules-based country) etc. We grouped the companies included in our sample based on the criteria above in order to emphasize the influence of different institutional factors on the reporting practices.

\section{Results and Discussion}

\subsection{The Comparability of GRI's Environmental Performance Indicators}

In this section we present the descriptive results concerning the comparability of EPIs, and particularly the energy and emissions indicators, for the entire sample for the year 2016. The indicators disclosed by companies and the weighted means of environmental disclosure for all the companies, environmentally sensitive companies and non-environmentally sensitive companies are presented in Table 3. 
Table 3. Number of companies disclosing at least an indicator.

\begin{tabular}{|c|c|c|c|c|}
\hline Indicator & Sensitive $(\max =10)$ & Non-Sensitive $(\max =25)$ & All Companies $(\max =35)$ & Difference \\
\hline 0 & 1 & 2 & 3 & $4=1-2$ \\
\hline Materials (average in \%) & $35.00 \%$ & $44.00 \%$ & $41.43 \%$ & $-9.00 \%$ \\
\hline G4-EN1 & 5 & 15 & 20 & \\
\hline G4-EN2 & 2 & 7 & 9 & \\
\hline Energy (average in \%) & $58.00 \%$ & $65.60 \%$ & $63.43 \%$ & $-7.60 \%$ \\
\hline G4-EN3 & 7 & 22 & 29 & \\
\hline G4-EN4 & 4 & 9 & 13 & \\
\hline G4-EN6 & 8 & 21 & 29 & \\
\hline G4-EN5 & 6 & 15 & 21 & \\
\hline G4-EN7 & 4 & 15 & 19 & \\
\hline Water (average in \%) & $66.67 \%$ & $26.67 \%$ & $38.10 \%$ & $40.00 \%$ \\
\hline G4-EN8 & 7 & 13 & 20 & \\
\hline G4-EN9 & 6 & 3 & 9 & \\
\hline G4-EN10 & 7 & 4 & 11 & \\
\hline Biodiversity (average in \%) & $52.50 \%$ & $17.00 \%$ & $27.14 \%$ & $35.50 \%$ \\
\hline G4-EN11 & 6 & 3 & 9 & \\
\hline G4-EN12 & 5 & 7 & 12 & \\
\hline G4-EN13 & 6 & 4 & 10 & \\
\hline G4-EN14 & 4 & 3 & 7 & \\
\hline Emissions (average in \%) & $70.00 \%$ & $65.14 \%$ & $66.53 \%$ & $4.86 \%$ \\
\hline G4-EN15 & 8 & 21 & 29 & \\
\hline G4-EN16 & 9 & 21 & 30 & \\
\hline G4-EN17 & 8 & 20 & 28 & \\
\hline G4-EN18 & 7 & 14 & 21 & \\
\hline G4-EN19 & 6 & 20 & 26 & \\
\hline G4-EN20 & 4 & 8 & 12 & \\
\hline G4-EN21 & 7 & 10 & 17 & \\
\hline Effluents and Waste (average in \%) & $62.00 \%$ & $33.60 \%$ & $41.71 \%$ & $28.40 \%$ \\
\hline G4-EN22 & 8 & 8 & 16 & \\
\hline G4-EN23 & 8 & 17 & 25 & \\
\hline G4-EN24 & 7 & 7 & 14 & \\
\hline G4-EN25 & 4 & 4 & 8 & \\
\hline G4-EN26 & 4 & 6 & 10 & \\
\hline Products and services (average in \%) & $30.00 \%$ & $26.00 \%$ & $27.14 \%$ & $4.00 \%$ \\
\hline G4-EN27 & 3 & 9 & 12 & \\
\hline G4-EN28 & 3 & 4 & 7 & \\
\hline Compliance (average in \%) & $60.00 \%$ & $36.00 \%$ & $42.85 \%$ & $24.00 \%$ \\
\hline G4-EN29 & 6 & 9 & 15 & \\
\hline Transport (average in \%) & $40.00 \%$ & $24.00 \%$ & $28.57 \%$ & $16.00 \%$ \\
\hline G4-EN30 & 4 & 6 & 10 & \\
\hline Overall (average in \%) & $60.00 \%$ & $33.00 \%$ & $40.71 \%$ & $27.00 \%$ \\
\hline G4-EN31 & 7 & 6 & 13 & \\
\hline G4-EN32 & 8 & 10 & 18 & \\
\hline G4-EN33 & 6 & 11 & 17 & \\
\hline G4-EN34 & 3 & 6 & 9 & \\
\hline Minimum & $30.00 \%$ & $17.00 \%$ & $27.14 \%$ & $4.00 \%$ \\
\hline Maximum & $70.00 \%$ & $65.60 \%$ & $66.53 \%$ & $40.00 \%$ \\
\hline Standard deviation & $13.74 \%$ & $16.61 \%$ & - & - \\
\hline
\end{tabular}

Source: the authors' compilation.

The EPIs are grouped by GRI in ten categories. The averages registered for eight of them are higher in the case of the environmentally-sensitive companies. Also, this category of companies registers averages higher than $50 \%$ for seven categories of indicators, while the non-sensitive companies register high averages for only two categories of indicators. These categories are Energy and Emissions, in line with the European priorities regarding the protection of the environment. We notice that the average percentage of reporting per category varies from $17 \%$ to $70 \%$. This shows that, along with the normative isomorphism (represented by the implementation of the GRI guidelines in all the companies included in our sample), there are other forces which drive the reporting of the entities. The institutionalization of the environmental reporting in a higher degree in the sensitive companies is a sign of mimetic isomorphism: the companies copy (and are encouraged to copy, for instance by the IIRC) the reporting practices of companies involved in similar activities. Also, it is a sign that the management systems 
in place in the environmentally-sensitive companies are more mature than in the case of the other companies [2,5].

The biggest number of indicators required by GRI is included in the Emissions category. They are followed by the Energy category. Also, the most disclosed categories of indicators at the level of the entire sample are the energy and emissions. These prove the importance of the energy and emissions reporting. The institutionalization of the reporting of these indicators is coercive, as they are required by laws and regulations in many countries.

The maximum score obtained at the level of the companies which use GRI (34) is registered by B (a company involved in an environmentally-sensitive industry). One company does not disclose any environmental indicator, even though it declares that it is applying the GRI guidelines.

The biggest number of companies (30) report the indicator related with the scope 2 emissions. The smallest number of companies (7) reports the indicators G4-EN28 Reclaimed products and their packaging materials and G4-EN14 Total number of IUCN red list species and national conservation list species with habitats in areas affected by operations, by level of extinction risk.

There are significant differences between the frequency of the categories of EPIs reported by the environmentally sensitive companies on the one hand and non-environmentally sensitive companies on the other hand. Our finding is in line with the previous research $[16,47]$. The companies involved in non-sensitive domains register higher averages for the categories Materials and Energy. This is justified by the fact that these two categories of indicators refer to resources used by all companies, irrespective of the industry they are part of. On the other hand, the production of energy does not require the use of raw materials. Thus, for the energy companies, Materials category is not a significant group of indicators. Companies which are not environmentally sensitive emphasize the presentation of these two categories of indicators. Within the two categories, there is no indicator whose name or presentation guidelines involves the disclosure of negative information. Furthermore, there are indicators that can be considered as having a positive environmental impact (e.g., G4-EN2 Recycled input materials used). This is an additional reason justifying the disclosure of this type of information and supports the results of [1].

All the other categories of indicators have been reported in a larger percentage by environmentally sensitive companies. The smallest difference between weights in which EPIs are reported (0-10) is recorded under the Products and services, respectively Emissions categories. For the first category, the difference between the EPI reporting weights was only $4 \%$. Reporting these indicators has positive connotations. In the case of the Emissions, the difference between the EPI reporting averages was only $4.86 \%$. Five of these indicators (EN15, EN16, EN17, EN18, EN19) have been reported by most of the non-sensitive companies. This has led to a contraction of the difference concerning the reporting weights between the two set of companies. These are indicators requested by other guidelines as well, such as the Greenhouse Gas Protocol.

The indicator disclosed under the Transport category takes into account both the transport of products and other goods and materials for the organization's operations, aspect specific for organizations in sensitive domains, as well as the transport of members of the workforce, which is specific to organizations in both categories.

A significant difference in terms of the average of information reported by the two types of companies is recorded in the categories: Compliance, Overall, respectively Effluents and Waste. In the Compliance category, the $42.85 \%$ difference between the two types of companies is justified by the fact that the specific regulations to be respected by environmentally sensitive companies are more numerous than those that are not sensitive to the environment. For the Overall category, the difference between the EPI reporting by the two types of companies is $40.71 \%$. This is justified by the fact that all of the indicators are largely related with environmental issues. A similar explanation justifies the $41.71 \%$ difference in the Effluents and Waste category. In terms of Biodiversity, environmentally sensitive firms have the greatest impact. Consequently, they report more than $50 \%$ of the specific 
indicators. Unlike these, only $17 \%$ of the non-sensitive firms report these indicators. The results are convergent with the ones reported by $[16,72]$.

On top of the most drained resources, water ranks first. This category of indicators is most frequently presented $(66.67 \%)$ by environmentally-sensitive firms, even if two of the three indicators included in this category have negative connotations (e.g., G4-EN9 Water sources significantly affected by withdrawal of water). Also, in this category of indicators the biggest difference regarding the frequency of the presentation, compared to the non-sensitive companies, was registered $(40.00 \%)$. The institutionalization of the disclosure of negative information in the environmentally-sensitive companies as a form of normative isomorphism shows that the CSR reporting reached a maturity level within these entities. The conclusion backs the results of $[8,10]$. The results for the Mann-Whitney Test conducted on sensitive and non-sensitive companies are presented in Table 4.

Table 4. Mann-Whitney test results.

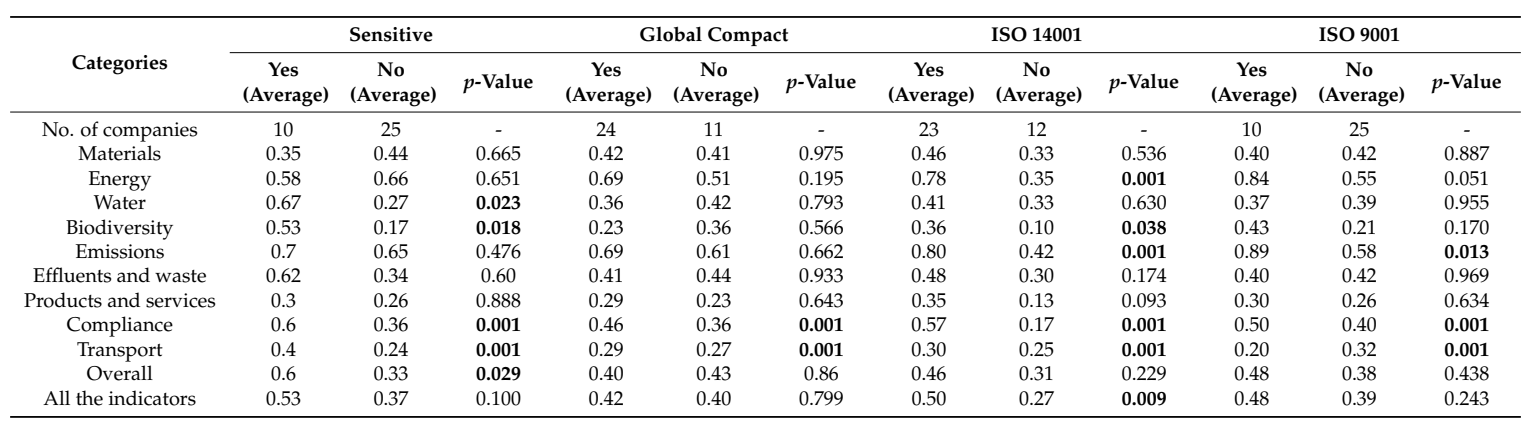

Source: the authors' compilation with XLStat; ${ }^{*}$ The statistically-significant tests are presented with bold.

The results obtained show that there is a significant difference between the number of indicators disclosed by the environmentally sensitive companies and the other companies for the following categories of indicators: Water, Biodiversity, Compliance, Transport, Overall. Also, the difference is statistically significant for the entire group of the environmental indicators. For energy and emissions the differences are not statistically significant from this point of view. The statistical results show that the implementation within the companies of other CSR instruments (in our case, Global Compact, ISO 14001, ISO 9001) is positively correlated with comparability. Energy and Emission comparability is correlated only with the use of ISO 14001. Our results are in line with the ones obtained by [28].

According to our results, the most disclosed EPIs are related with the Energy and Emissions categories. In the next step of our analysis we applied NVivo in order to see which were the most frequently used words in respect of environment. The results are presented in Figure 2. 


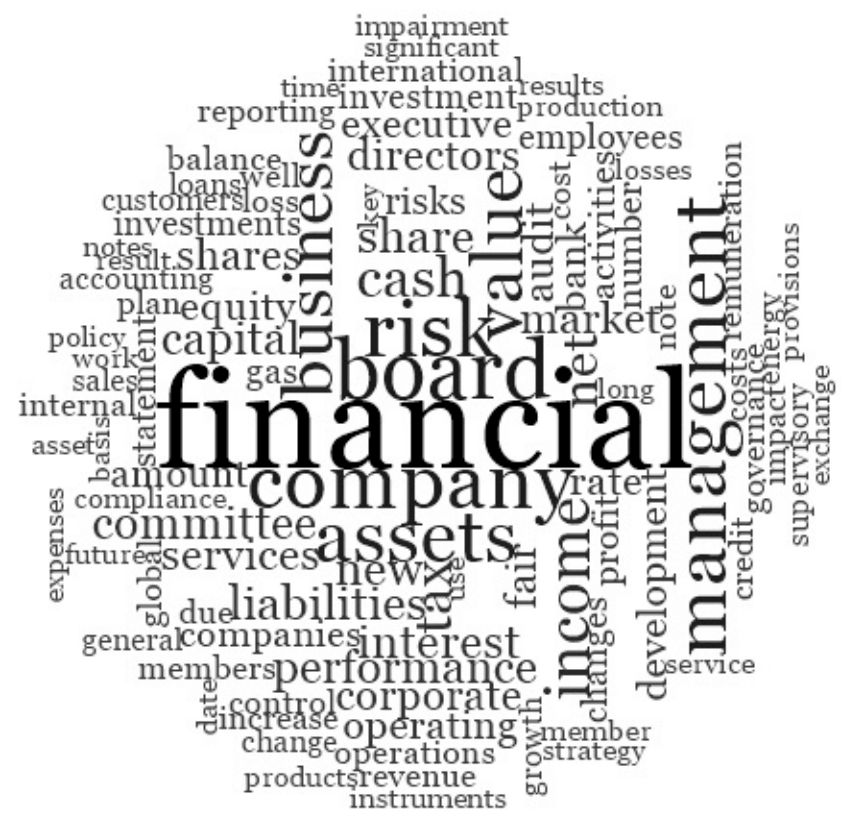

Figure 2. The most used words in the 2016 reports.

The frequency of use of the words related with the categories of EPIs is presented in Table 5.

Table 5. Frequency of use of the words related with EPIs.

\begin{tabular}{ccc}
\hline Word & Place & Frequency \\
\hline Services & 35 & 7285 \\
Gas & 65 & 5120 \\
Energy & 101 & 3947 \\
Compliance & 110 & 3663 \\
Products & 128 & 3428 \\
Emissions & 278 & 2021 \\
Overall & 512 & 1243 \\
Water & 521 & 1235 \\
Materials & 602 & 1094 \\
Waste & 660 & 997 \\
Transport & 850 & 759 \\
Biodiversity & 0 & 0 \\
Effluents & 0 & 0 \\
\hline
\end{tabular}

Source: data extracted with NVivo.

The frequency of the use of words and the places obtained by them prove once again the importance of the energy and emissions reporting. We notice that the word gas is the second most reported and it appears 5120 times in the reports. It is followed by the word energy. The consistent reporting is supported by the use of the word emissions for 2021 times.

\subsection{The Consistency of GRI's Environmental Performance Indicators}

We investigated 30 reports published by the 10 environmentally sensitive companies. The review of the results is performed in order to determine a score of EPI consistency for each organization. The scores of the EPI consistency is displayed in Table 6. 
Table 6. The score of the EPI consistency.

\begin{tabular}{|c|c|c|c|c|}
\hline Organizations & Total Score & Number of Indicators & Average Score & Number of GRI Versions \\
\hline 0 & 1 & 2 & $3=1 / 2$ & 4 \\
\hline \multicolumn{5}{|c|}{ Basic Materials/Chemicals } \\
\hline A & 12 & 10 & 1.20 & 3 \\
\hline $\mathrm{B}$ & 14 & 12 & 1.17 & 3 \\
\hline $\mathrm{C}$ & 19 & 11 & 1.73 & 3 \\
\hline Mean & 15.00 & 11.00 & 1.36 & 3 \\
\hline Median & 14.00 & 11.00 & 1.20 & 3 \\
\hline \multicolumn{5}{|c|}{ Industrials } \\
\hline $\mathrm{D}$ & 23 & 12 & 1.92 & 3 \\
\hline $\mathrm{E}$ & 15 & 13 & 1.15 & 3 \\
\hline $\mathrm{F}$ & 12 & 6 & 2.00 & 3 \\
\hline Mean & 16.67 & 10.33 & 1.69 & 3 \\
\hline Median & 15.00 & 12.00 & 1.92 & 3 \\
\hline \multicolumn{5}{|c|}{ Oil \& Gas } \\
\hline G & 21 & 12 & 1.75 & 3 \\
\hline $\mathrm{H}$ & 17 & 14 & 1.21 & 3 \\
\hline I & 23 & 14 & 1.64 & 2 \\
\hline $\mathrm{J}$ & 11 & 8 & 1.38 & 2 \\
\hline Mean & 18.00 & 12.00 & 1.50 & 2.5 \\
\hline Median & 19.00 & 13.00 & 1.51 & 2.5 \\
\hline No. of organizations & 10 & 10 & 10 & 10 \\
\hline Mean & 16.70 & 11.20 & 1.51 & 2.8 \\
\hline Min & 11 & 6 & 1.15 & 2 \\
\hline Max & 23 & 14 & 2.00 & 3 \\
\hline Standard deviation & 4.60 & 2.57 & 0.33 & 0.42 \\
\hline Median & 16.00 & 12.00 & 1.51 & 3 \\
\hline
\end{tabular}

Confirming previous research [13,28-30], we noticed that the published environmental information was different both in terms of disclosure and manner of determining the values of the investigated indicators.

We notice that the best results regarding the consistency are obtained by the companies involved in the Oil $\mathcal{E}$ Gas industry. They report consistently on the biggest number of indicators-on average, 12 out of 18 indicators are present in the reports released by this category of companies in all the three investigated years. Two companies in this industry also report the biggest number of indicators in the sample (14 EPIs for companies ' $\mathrm{H}$ ' and ' $\mathrm{I}$ '). After granting the consistency scores, company ' $\mathrm{I}$ ' obtains the biggest total score. The results obtained show the concern of the companies involved in the Oil \& Gas industry for the environmental reporting. The existence of the G4 'Electric Utilities Sector Disclosures' leads to normative isomorphism and improves consistency [75].

As shown by [1], an aspect affecting the information consistency during the three reporting periods was the lack of determining certain information. For example, the organization $\mathrm{C}$ has a score above average in respect of consistency (1.73) though it discloses 11 indicators. The value of the consistency score could be sustained by discontinuing indicator disclosure (for example, in 2016 for the indicator 305-6 'Emissions of ozone-depleting substances', $\mathrm{C}$ mentions the following: 'not applicable'. ' $\mathrm{C}$ ' doesn't report the indicator 305-6 anymore because priority is given to other indicators' [76]). In respect of the other two organizations from the Basic Materials we notice the existence of a similar score regarding consistency (respectively 1.20 and 1.17) and number of 10 and respectively 12 indicators. They also keep the same measurement units during each of the three years.

Among the factors which have generated the decrease of information consistency for the companies belonging to the Industrials/Transportation industry we notice the reporting of new 
indicators, the change in the manner of their detailed description or giving up on certain indicators once other GRI guidelines entered into use. Similar results were obtained by [31-33]. In this respect, we give several representative examples:

- The organization ' $\mathrm{D}$ ' reported information on the indicators EN 17 'Other indirect greenhouse gas (GHG) emissions (Scope 3)' (G3.0), respectively EN 24 'Weight of transported, imported, exported, or treated waste deemed hazardous under the terms of the Basel Convention Annex I, II, III, and VIII, and percentage of transported waste shipped internationally' (G3.0) for the first time in 2013, and on the indicator EN10 'Percentage and total volume of water recycled and reused' (G4) in 2016;

- The organization 'E' presented information on the indicator EN 19 'Emissions of ozone-depleting substances by weight' (G3.1) for the first time in 2013. In 2016, beginning with the SRS application, it changed the manner of detailing the disclosed information;

- The organization ' $\mathrm{F}$ ' presented the indicator EN20 ` $\mathrm{NO}, \mathrm{SO}$, and other significant air emissions by type and weight' (G3.0) only in 2010; in the following years it gave up presenting them. Also, the indicator EN3 'Direct energy consumption by primary energy source' was presented only in 2010 and 2013 (G3.0 and G3.1).

The consistency was affected by the change in the GRI guidelines used. All the companies used two or three versions of GRI. For the year 2010, we find that two of the organizations (' $A$ ' and ' $C$ ') included in the Basic Materials/Chemicals industry, though they refer to GRI and report information for the GRI databases, do not mention the use of any GRI version, only citing GRI. This led to a lower degree of consistency of information (Table 6). One organization (' $\mathrm{B}^{\prime}$ ) used the G3 version. In 2013 there were also used different versions of the GRI references, such as: G3.1 version by ' $A$ ', and the G4 version by the rest of the organizations. In the last reviewed year, two of the organizations (' $\mathrm{A}$ ', ' $\mathrm{B}$ ') used the G4 version, and one ('C') used the new SRS for reporting. Our finding raises the question of the utility of convergent reporting standards, in line with [28,47].

At the level of the organizations belonging to the Industrials/Transportation there is the biggest number of differences in terms of the sustainability reporting guidelines. The following versions were used: G3.0, G3.1, G4 and SRS. A specific aspect of the investigated organizations within this industry is given by the fact that for each examined year all the four organizations used different versions of GRI reporting, such as: in 2010 'D' did not use the GRI reference, and the other two organizations used the G3.0 version, in 2013 all three organizations used the G3.1 version, and in 2016 E used SRS, the other two organizations using the G4 version.

Once again, the results regarding the consistency obtained by the companies included in the Oil \& Gas industry are the best. There were used the fewest versions of GRI: G3.0, G3.1 and G4. Two ('I 'and 'J') out of the four organizations used the same version (G4) for two of the three reporting periods under investigation. At year level the situation is the following: in 2010 all organizations used the G3.0 version, in 2013 two organizations (' $\mathrm{G}$ ' and ' $\mathrm{H}$ ') used the G3.1 version and two organizations used the G4 version, and in 2016 all of them used the G4 version. There can be noticed the fact that at the level of this industry there is the highest uniformity in terms of using the same version of guideline in the same year.

Overall, we noticed a few aspects that made the information consistency worse. The symbols used for indicators have changed in time, along with the guidelines used. There are situations when the same symbol is used to disclose totally different information in case of using different versions of the reporting guidelines. For example, for the sign EN5 the following names have been associated: 'Energy saved due to conservation and efficiency improvements' (G3.0/3.1), respectively 'Reduction of energy consumption' (G4). Also, there are situations when, for a similar name and content of an indicator, the signs are different, according to the version of the references under investigation. An example in this respect is the indicator 'Direct greenhouse gas (GHG) emissions (Scope 1)', represented within 
references under the following symbols: EN16 (G3.0/3.1), EN15 (G4), respectively 305-1 (SRS). Similar aspects and consequences regarding the consistency were reported by [32].

Second, the symbol of the indicator has remained the same within various versions of the references (G3.0/G3.1, G4) in the case of most of the indicators, and in respect of the name, there have been insignificant variations. Yet for some EPIs, the symbol of the indicator has remained the same within various versions of the guidelines, and the content of the disclosed information is completely different. Such an example is the indicator EN2, whose name has been changed as: 'Percentage of materials used that are recycled input materials' (G3.0/3.1, G4). In this case there could be seen that the focus turned from disclosing a negative aspect (waste) to presenting a positive aspect (recycled materials).

Third, the manner of reporting the environmental information has changed in time. One of the main causes was the change of the GRI references. Although we reviewed the existing indicators in all the versions, the guidelines related to these indicators [66-69] offered slightly changed indications regarding their disclosure, which led to a different detail level. Also, analyzing the names of the indicators disclosed in Appendix B, we notice slight changes in names from version to version inducing, to a greater or lower extent, the idea of a quantitative disclosure. For example, in G3.0, G3.1 and G4 versions the name of the same indicator was changed into 'Percentage and total volume of water recycled and reused', and in SRS the name of the same indicator was 'Water recycled and reused'.

Another factor, of psychological nature, which could affect the users' perception in respect of indicators' consistency, is the change of the used measurement unit for different reporting periods. This aspect was observed for many indicators within all analyzed industries. In this respect, we select several examples in Table 7.

Table 7. Differences in terms of the used measurement units.

\begin{tabular}{ccccc}
\hline Organization & Indicator & $\mathbf{2 0 1 0}$ & $\mathbf{2 0 1 3}$ & $\mathbf{2 0 1 6}$ \\
\hline $\mathrm{C}$ & $306-2$ 'Waste by type and disposal method' & 3658 kilotons & $1,688,882$ tons & 1463 metric tons \\
(e.g., non-hazardous waste) & 303-1 'Total water withdrawal by source' & $549,240 \mathrm{~m}^{3}$ & - & over 1.8 Mn cubic metres \\
I & $\begin{array}{c}\text { 302-1 'Energy consumption within } \\
\text { the organization' }\end{array}$ & $3.997 \times 10^{16} \mathrm{~J}$ & $2.58 \times 10^{17} \mathrm{~J}$ & 338.2 million gigajoules \\
\hline
\end{tabular}

Source: compilation of the authors.

This change of the measurement unit used for information disclosure could generate confusion for an uninformed user, giving the false impression that the value of an indicator has improved or worsened substantially. Although, if there had been used the same measurement unit, there would have been visible the fact that the values could be compared. This finding supports the results of [38].

For certain information the order of information disclosure changed from year to year. If in 2010 all the organizations started the detailed presentation of information related to the indicator 306-2 'Waste by type and disposal method with hazardous waste followed by non-hazardous waste' with the hazardous waste, in the further investigated reports we notice that some organizations inversed the disclosure order beginning with the non-hazardous waste (e.g., in 2013 the organization 'B').

Another aspect is that, although an organization did not disclose some information in a report for various reasons (e.g., not available, not applicable, not material), three years later, that organization presented compared information for the previous periods. An example in this respect is the one of A which, in 2013, mentioned the fact that total environmental protection expenditures and investments by type are not applicable because the 'environment is part of overall investment analysis'. In 2016 it presented this information in comparison with the existing values in 2013 . This finding is in line with [2].

In the case of ' $G$ ' we identified inconsistencies regarding the direct GHG emissions. The situation is presented in Table 8. 
Table 8. Inconsistencies regarding the disclosure of the GHG emissions.

\begin{tabular}{cccccccc}
\hline Year of the Report & $\mathbf{2 0 0 8}$ & $\mathbf{2 0 0 9}$ & $\mathbf{2 0 1 0}$ & $\mathbf{2 0 1 1}$ & $\mathbf{2 0 1 2}$ & $\mathbf{2 0 1 3}$ & $\mathbf{2 0 1 4}$ \\
\hline Direct GHG emissions (declared in 2016) & & & 48.7 & 52.1 & 47.6 & 42.0 & 41.6 \\
$\begin{array}{l}\text { Direct GHG emissions (declared in 2013) } \\
\text { Direct GHG emissions (declared in 2010) }\end{array}$ & 61.99 & 57.66 & 60.68 & & & & \\
\hline
\end{tabular}

Source: authors' compilation.

We analysed the consistency with past performance and the consistency with the objectives for the ten environmentally-sensitive companies included in our sample. The results regarding the consistency with past performance show that the companies present the key figures for at least two years. In 2013 and 2016 a few companies present as well the differences registered as to the previous period. Thus, we can conclude that the companies comply with this part of the consistency and comparability principle.

In terms of consistency with the objectives, we noticed first that all the companies included plans, goals, targets. The period refers in general to a further period, such as, for instance, to 2020 . Sometimes the objectives are not accompanied by any discussion. Also, in 2010 the companies do not present how they complied with the plans set in the previous years. The objectives do not cover all the material environmental items. Most of them refer to energy and emissions EPIs. Overall, we notice an improvement in the disclosure from this point of view. This finding is an indication of normative isomorphism. As the environmental reporting matures and is professionalized, the normative isomorphism (in our case, the institutionalization of the consistency and comparability principle) becomes more important [74].

\section{Conclusions}

Reporting is important as it can lead to improvement in CSR performance. Consistency and comparability are required by stakeholders and are characteristics of qualitative information. Without rules consistency and comparability cannot be achieved.

Our study is twofold. First, in order to assess the comparability, we analyse the GRI indicators disclosed in 2016 by all the European companies included in the IIRC's PP. We analysed all the types of environmental indicators suggested by the GRI, unlike other studies which focus on output indicators [77]. Also, we did not analyse only the energy and emissions indicators because we consider that the importance of these categories is better emphasized when compared to others. We split the sample using various institutional variables: the impact of the industry on the environment; participation in CSR networks (member of the United Nations Global Compact); adoption of voluntary reporting standards (such as the GRI); adoption of other standards (ISO 14001 or ISO 9001); source of capital (public or private); stock exchange listing; auditor (Big 4 or another auditor). Yet, the number of companies included in the sample owned by the State, not listed at a stock exchange or not audited by a Big 4 was very small. As such, these criteria could not be used in our analysis. There are ten categories of EPIs required by GRI. The most disclosed categories are Energy and Emissions. This is because of their impact on the environment and because of the EU's policies which integrate various aspects (e.g., energy, efficiency, emissions, reporting). EU is acting as a driver of CSR policy. In line with $[16,78]$, we noticed that the environmentally-sensitive companies published significantly more indicators. One exception to the rule is that for indicators in the Materials and Energy categories. There was a higher reporting frequency among non-sensitive companies for these categories, which can be justified by the fact that in these categories there are general indicators and there is no indicator with negative connotations. We showed the firms' preference for presenting positive environmental information confirming previous research [1,74,79-81]. In addition, companies that are not environmentally sensitive have the tendency to present extensively the indicators they have information about, confirming the results of [33]. We observed that the indicators regarding water (EN8, EN9 and EN10) are most frequently presented (66.67\%) by environmentally-sensitive companies, even if two of the three indicators included in this category have negative meaning. This proves that 
the CSR systems in force in the environmental-sensitive companies are more mature. Moreover, in this category of indicators the biggest difference regarding the frequency of the presentation, compared to the non-sensitive companies was registered $(40.00 \%)$. The most disclosed indicators overall refer to the Energy and Emissions categories. These show the importance of these indicators for all the companies.

Second, in order to assess the consistency, we compared the quantitative EPIs disclosed by the organizations involved in environmentally-sensitive industries, in the context of the changes in the environmental reporting. In order to do this, we determined a score of information consistency for each organization. In line with previous research $[16,39,40]$, we analysed the data on industries. Overall, the number of indicators reported consistently by the examined companies range from 6 to 14 and the degree of consistency (1.51) is above the theoretical mean (1.50). The industry where there was observed the highest level of consistency is Basic Materials (mean of 1.36, median of 1.20), followed by Oil \& Gas (mean of 1.50, median of 1.51) and Industrials (mean of 1.69, median of 1.92). In addition, there can be seen that within the industry with the lowest degree of consistency (Industrials) there was the highest oscillation in respect of the number of applied versions of the GRI guidelines. In each of the three years there was applied another version of the GRI references. These findings show that the change of the used version of the GRI references was one of the factors affecting the information consistency. The consistency was affected by the variety in methodologies applied, supporting the results of $[32,38]$.

In the situations when, under the same sign of the indicators, there is disclosed various information or there are used different symbols for presenting the same type of information, in accordance to the used references, we estimate that the degree of information consistency is more difficult to be achieved, especially for the less informed users. As a consequence, 'reports appear to be vastly underutilized due to insufficient knowledge of and skills for assessing corporate sustainability information' [82].

We need research in order to find solutions to address the environmental challenges. The introduction of international guidelines is useful in reaching consistency and comparability, but the convergence is not achieved yet.

The consistency and comparability are affected by the fact that the companies conduct business outside Europe as well. Even though the EU enforced directives and established national environment agencies, these are only applied in Europe and for the other countries the data is asymmetric.

We use the institutional theory in our research. We notice that the use of GRI was not enough to assure the consistency and comparability. GRI guidelines are not applied consistently across firms and countries because of tradition and institutional variables. We notice from Table 3 that there are material differences, even though the entire sample applies the GRI. It results that reporting is influenced by various coercive, normative and mimetic institutions. In this respect, our results are consistent with de $[5,72,74]$. Most of the companies included in our sample improved the consistency and comparability of EPIs after the institutionalization of integrated reporting. The companies included gradually more environmental information in their reports; the information was better presented (e.g., targets, analysis). Integrated reporting is not mandatory. Thus, this is an example of normative isomorphism. Our findings are in line with the ones obtained by [72]. Other factors influencing the comparability were the adherence to the Global Compact, the adoption of ISO 14001 and ISO 9001. Different standards ask for different indicators. So, their application was statistically correlated with different categories of EPIs.

The improvement in consistency and comparability can be associated with a new form of isomorphism-the isomorphism by template [74]. It is argued that the use of a template (in our case the GRI guidelines) can improve the consistency and comparability, but this won't generate necessarily an improvement in the CSR practices and performance. As such, the requirements of the guidelines are recommended, not compulsory. 'An organization is not required to comply with recommendations or guidance in order to claim that a report has been prepared in accordance with the Standards.' ([69], p. 5). There are no consequences or penalties for omitting indicators. Thus, we found that the companies in our sample report a number of EPIs ranging from 0 to 34, but all of them are declaring that they 
are applying the GRI guidelines. Also, the (external) assurance is not compulsory, but recommended. This leads to a decrease in the reliability of the information reported. The application levels could be self-declared by the organization and in this case GRI has to be notified. In order to increase the reputation of the organization, it is advisable to select organizations for external organization and, although allowed by GRI, to avoid situations in which they do not report certain aspects. An increased reputation of an organization leads to increased customer loyalty and implicitly to increased profit [83].

The lack of reporting is a result itself. 14 companies do not include environmental information in their integrated reports. The words 'biodiversity' and 'effluents' are not included in any reports, even though they are main categories in the GRI guidelines.

Along with the consistency and comparability, another variable which could be considered as influencing CSR reporting is materiality. The companies can report on what they consider material to distract the attention of the stakeholders from the existence of a possible comparability which can reflect negative results or decreases as to the targeted objectives. On the background of the continuous changes in the guidelines, they can postpone the achievement of the consistency.

A limit of our research is the small number of companies selected. Yet, we searched for the information in many reports. Also, as the number of companies included in the Pilot Program was less than 100 , we considered that we analysed a fair number of companies.

Our study brings a contribution showing the impact of a voluntary standard (the GRI) on two important characteristics of the environmental information - the consistency and comparability. The study also shows the comparability and consistency of reports published by organizations until the year before the application of Directive 2014/95, which will led to an increase in coercive isomorphism.

Our study can have an impact in practice. There are implications for practitioners and assurance providers of integrated reports, standard setters and regulators [37]. The representatives of the organisations can see how the compliance with the guidelines is assessed (in our case, the compliance with the consistency and comparability principles) and can improve their reporting process. A better reporting can have a positive effect on the organisation's reputation, profit and customer loyalty [83]. Also, eventually, it should be in the benefit of the society. As mentioned before, this is a first study analysing, int the same time, the principles of consistency and comparability in the area of environmental disclosures. Another contribution lies in the approach of these two principles; consistency and comparability are highly correlated: one leads to the other and backwards. This suggests that not only entities can improve their reporting, but also investors can assess the companies' communication and ask for some form of assurance that what was declared has actually happened in that firm.

Author Contributions: Conceptualization, M.D.; Investigation, V.A., D.A.C. and M.E.G.; Methodology, V.A., D.A.C., M.D. and G.J.; Project administration, M.D.; Software, V.F.D., M.D. and G.J.; Visualization, M.D.; Writing—original draft, V.A., D.A.C. and G.J.

Funding: This research received no external funding.

Conflicts of Interest: The authors declare no conflict of interest.

\section{Nomenclature}

$\begin{array}{ll}\text { C } & \text { Criteria } \\ \text { CSR } & \text { Corporate Social Responsibility } \\ \text { ED } & \text { European Directive } \\ \text { EMAS } & \text { Eco-Management and Audit Scheme } \\ \text { EN } & \text { Environmental } \\ \text { EPI } & \text { Environmental performance indicators } \\ \text { EU } & \text { European Union } \\ \text { G } & \text { Guidelines } \\ \text { GHG } & \text { Greenhouse Gas } \\ \text { GRI } & \text { Global Reporting Initiative }\end{array}$


IEA International Energy Agency

IIRC International Integrated Reporting Council

IIRC's PP International Integrated Reporting Council's Pilot Programme

IIRF International Integrated Reporting Framework

ISO International Organization for Standardization

ODS Ozone-depleting substances

RE Renewable energy

SRS Sustainability Reporting Standards

PV Photovoltaic

UK United Kingdom

Appendix A.

Table A1. Environmentally-sensitive companies.

\begin{tabular}{|c|c|c|c|}
\hline Organizations & Countries & Years & GRI Version \\
\hline \multicolumn{4}{|c|}{ Basic Materials/Chemicals (3) } \\
\hline \multirow{3}{*}{ A } & \multirow{3}{*}{ The Netherlands } & 2010 & Citing GRI \\
\hline & & 2013 & G3.1 \\
\hline & & 2016 & G4 \\
\hline \multirow{3}{*}{$\mathrm{B}$} & \multirow{3}{*}{ Germany } & 2010 & G3.0 \\
\hline & & 2013 & G3.1 \\
\hline & & 2016 & G4 \\
\hline \multirow{3}{*}{$\mathrm{C}$} & \multirow{3}{*}{ Belgium } & 2010 & Citing GRI \\
\hline & & 2013 & G4 \\
\hline & & 2016 & SRS \\
\hline \multicolumn{4}{|c|}{ Industrials/Transportation (3) } \\
\hline \multirow{3}{*}{$\mathrm{D}$} & \multirow{3}{*}{ Italy } & 2010 & - \\
\hline & & 2013 & G3.1 \\
\hline & & 2016 & G4 \\
\hline \multirow{3}{*}{$\mathrm{E}$} & \multirow{3}{*}{ Germany } & 2010 & G3.0 \\
\hline & & 2013 & G3.1 \\
\hline & & 2016 & SRS \\
\hline \multirow{3}{*}{$\mathrm{F}$} & \multirow{3}{*}{ The Netherlands } & 2010 & G3.0 \\
\hline & & 2013 & G3.1 \\
\hline & & 2016 & G4 \\
\hline \multicolumn{4}{|c|}{ Oil \& Gas (4) } \\
\hline \multirow{3}{*}{ G } & \multirow{3}{*}{ Italy } & 2010 & G3.0 \\
\hline & & 2013 & G3.1 \\
\hline & & 2016 & G4 \\
\hline \multirow{3}{*}{$\mathrm{H}$} & \multirow{3}{*}{ Spain } & 2010 & G3.0 \\
\hline & & 2013 & G3.1 \\
\hline & & 2016 & G4 \\
\hline \multirow{3}{*}{$\mathrm{I}$} & \multirow{3}{*}{ Russian Federation } & 2010 & G3.0 \\
\hline & & 2013 & G4 \\
\hline & & 2016 & G4 \\
\hline \multirow{3}{*}{$\mathrm{J}$} & \multirow{3}{*}{ Italy } & 2010 & G3.0 \\
\hline & & 2013 & G4 \\
\hline & & 2016 & G4 \\
\hline
\end{tabular}


Appendix B.

Table A2. Comparative Analysis of Environmental Indicators.

\begin{tabular}{|c|c|c|c|}
\hline $\begin{array}{l}\text { G3.0/3.1 (2006/2011) } \\
\quad-1-\end{array}$ & $\begin{array}{l}\text { G4 (2013) } \\
-2-\end{array}$ & $\begin{array}{l}\text { SRS (2016) } \\
-3-\end{array}$ & GRI Environmental Indicators \\
\hline G3.0/3.1-EN1 & G4-EN1 & $301-1$ & 'Materials used by weight or volume' $(1,2,3)$ \\
\hline G3.0/3.1-EN2 & G4-EN2 & $301-2$ & 'Percentage of materials used that are recycled input materials' $(1,2) /{ }^{\prime}$ Recycled input materials used' (3) \\
\hline G3.0/3.1-EN3 & G4-EN3 & $302-1$ & 'Direct energy consumption by primary energy source' (1)/'Energy consumption within the organization' $(2,3)$ \\
\hline G3.0/3.1-EN4 & G4-EN4 & $302-2$ & 'Indirect energy consumption by primary source' (1)/'Energy consumption outside of the organization' $(2,3)$ \\
\hline G3.0/3.1-EN5 & G4-EN6 & $302-4$ & 'Energy saved due to conservation and efficiency improvements' (1)/'Reduction of energy consumption' $(2,3)$ \\
\hline G3.0/3.1-EN8 & G4-EN8 & $303-1$ & 'Total water withdrawal by source' $(1,2,3)$ \\
\hline G3.0/3.1-EN10 & G4-EN10 & $303-3$ & 'Percentage and total volume of water recycled and reused' $(1,2) /{ }^{\prime}$ Water recycled and reused' $(3)$ \\
\hline G3.0/3.1-EN15 & G4-EN14 & $304-4$ & $\begin{array}{l}\text { 'Number of IUCN red list species and national conservation list species with habitats in areas affected by operations, by } \\
\text { level of extinction risk' (1)/'Total number of IUCN red list species and national conservation list species with habitats in } \\
\text { areas affected by operations, by level of extinction risk' (2)/'IUCN red list species and national conservation list species } \\
\text { with habitats in areas affected by operations' (3) }\end{array}$ \\
\hline G3.0/3.1-EN16 & G4-EN15 & $305-1$ & 'Direct greenhouse gas (GHG) emissions (Scope 1)' (2)/'Direct (Scope 1) GHG emissions' (3) \\
\hline G3.0/3.1-EN17 & G4-EN17 & $305-3$ & 'Other indirect greenhouse gas (GHG) emissions (Scope 3)' (1,2)/‘Other indirect (Scope 3) GHG emissions' (3) \\
\hline G3.0/3.1-EN19 & G4-EN20 & $305-6$ & 'Emissions of ozone-depleting substances by weight' (1)/'Emissions of ozone-depleting substances (ODS)' $(2,3)$ \\
\hline G3.0/3.1-EN20 & G4-EN21 & $305-7$ & $\begin{array}{l}\text { 'NO, } \mathrm{SO} \text {, and other significant air emissions by type and weight' /'NOX, } \mathrm{SO}_{X} \text {, and other significant air emissions' } \\
(1,2) / \text { 'Nitrogen oxides }(\mathrm{NO})_{x} \text {, sulfur oxides }\left(\mathrm{SO}_{\mathrm{X}}\right) \text {, and other significant air emissions' (3) }\end{array}$ \\
\hline G3.0/3.1-EN21 & G4-EN22 & $306-1$ & 'Total water discharge by quality and destination' $(1,2) /$ 'Water discharge by quality and destination' (3) \\
\hline G3.0/3.1-EN22 & G4-EN23 & $306-2$ & 'Total weight of waste by type and disposal method' $(1,2) /{ }^{\prime}$ Waste by type and disposal method' (3) \\
\hline G3.0/3.1-EN23 & G4-EN24 & $306-3$ & 'Total number and volume of significant spills' $(1,2) /$ 'Significant spills' (3) \\
\hline G3.0/3.1-EN24 & G4-EN25 & $306-4$ & $\begin{array}{l}\text { 'Weight of transported, imported, exported, or treated waste deemed hazardous under the terms of the Basel Convention } \\
\text { Annex I, II, III, and VIII, and percentage of transported waste shipped internationally' (1)/'Weight of transported, } \\
\text { imported, exported, or treated waste deemed hazardous under the terms of the Basel Convention 2' (2)/'Transport of } \\
\text { hazardous waste' (3) }\end{array}$ \\
\hline G3.0/3.1-EN27 & G4-EN28 & $301-3$ & $\begin{array}{l}\text { 'Percentage of products sold and their packaging materials that are reclaimed by category' }(1,2) /{ }^{\prime} \text { Reclaimed products and } \\
\text { their packaging materials' (3) }\end{array}$ \\
\hline G3.0/3.1-EN28 & G4-EN29 & $307-1$ & $\begin{array}{l}\text { 'Monetary value of significant fines and total number of non-monetary sanctions for non-compliance with environmental } \\
\text { laws and regulations' (2)/'Non-compliance with laws or regulations' (3) }\end{array}$ \\
\hline
\end{tabular}




\section{References}

1. Boiral, O.; Henri, J. Is Sustainability Performance Comparable? A Study of GRI Reports of Mining Organizations. Bus. Soc. 2015, 56, 283-317. [CrossRef]

2. Dragomir, V.D. Sustainability Reporting: A Case for Corporate Accountability, 1st ed.; ASE Publishing House: Bucharest, Romania, 2012.

3. EY. Is Your Nonfinancial Performance Revealing the True Value of Your Business to Investors? 2017. Available online: https://www.ey.com/Publication/vwLUAssets/EY_-_Nonfinancial_performance_may_influence_ investors / \$FILE/ey-nonfinancial-performance-may-influence-investors.pdf (accessed on 22 July 2018).

4. Kolk, A. A decade of sustainability reporting: Developments and significance. Int. J. Environ. Sustain. Dev. 2004, 3, 51-64. [CrossRef]

5. Bebbington, J.; Larrinaga, C.; Moneva, J.M. Corporate social reporting and reputation risk management. Acc. Audit. Acc. J. 2008, 21, 337-361. [CrossRef]

6. Michelon, G. Sustainability Disclosure and Reputation: A Comparative Study. Corp. Reputat. Rev. 2011, 14, 79-96. [CrossRef]

7. Center for Corporate Citizenship; EY, Value of Sustainability Reporting. Available online: http: / / www.confluencellc.com/uploads/3/7/9/6/37965831/valueofsustainabilitysummary.pdf (accessed on 22 July 2017).

8. Adams, C.A.; McNicholas, P. Making a difference: Sustainability reporting, accountability and organisational change. Acc. Audit. Acc. J. 2007, 20, 382-402. [CrossRef]

9. Epstein, M.J.; Roy, M.J. Sustainability in Action: Identifying and Measuring the Key Performance Drivers. Long Range Plan. 2001, 34, 585-604. [CrossRef]

10. Robinson, H.S.; Anumba, C.J.; Carrillo, P.M.; Al-Ghassani, A.M. STEPS: A knowledge management maturity roadmap for corporate sustainability. Bus. Process Manag. J. 2006, 12, 793-808. [CrossRef]

11. Lozano, R.; Huisingh, D. Inter-linking issues and dimensions in sustainability reporting. J. Clean. Prod. 2011, 19, 99-107. [CrossRef]

12. Berns, M.; Townend, A.; Khayat, Z.; Balagopal, B.; Reeves, M.; Hopkins, M.S.; Kruschwitz, N. Sustainability and Competitive Advantage. MIT Sloan Manag. Rev. 2009, 51, 19-26.

13. KPMG. KPMG International Survey of Corporate Responsibility Reporting 2005. Available online: https: / / commdev.org/userfiles/files/1274_file_D2.pdf (accessed on 21 July 2018).

14. KPMG. The KPMG Survey of Corporate Responsibility Reporting 2017. Available online: https:/ / assets.kpmg.com/content/dam/kpmg/xx/pdf/2017/10/kpmg-survey-of-corporateresponsibility-reporting-2017.pdf (accessed on 21 July 2018).

15. KPMG, GRI, UNEP Centre for Corporate Governance in Africa 2016. Carrots \& Sticks. Global Trends in Sustainability Reporting Regulation and Policy. Available online: https://assets.kpmg.com/content/dam/ kpmg/pdf/2016/05/carrots-and-sticks-may-2016.pdf (accessed on 7 August 2017).

16. Barbu, E.; Dumontier, P.; Feleagă, N.; Feleagă, L. Mandatory Environmental Disclosures by Companies Complying with IASs/IFRSs: The Cases of France, Germany, and the UK. Int. J. Acc. 2014, 49, $231-247$. [CrossRef]

17. Saghroun, J.; Eglem, J.Y. A la recherche de la performance globale de l'entreprise: La perception des analystes financiers. Comptab. Contrôl. Audit 2008, 1, 93-118. [CrossRef]

18. World Economic Forum. Accelerating the Transition towards Sustainable Investing-Strategic Options for Investors, Corporations and Other Key Stakeholders; World Economic Forum: Geneva, Switzerland, 2011.

19. De Villiers, C.; Rouse, P.; Kerr, J. A New Conceptual Model of Influences Driving Sustainability Based on Case Evidence of The Integration of Corporate Sustainability Management Control and Reporting. J. Clean. Prod. 2016, 136, 78-85. [CrossRef]

20. Tilling, M.V.; Tilt, C.A. The edge of legitimacy. Voluntary social and environmental reporting in Rothmans' 1956-1999 annual reports. Acc. Audit. Acc. J. 2010, 23, 55-81. [CrossRef]

21. O'Donovan, G. Environmental disclosures in the annual report. Extending the applicability and predictive power of legitimacy theory. Acc. Audit. Acc. J. 2002, 15, 344-371. [CrossRef]

22. Global Reporting Initiative, Sustainability Reporting Guidelines 2002. Available online: https:/ / www.epeat. net/documents/EPEATreferences/GRIguidelines.pdf (accessed on 15 January 2017). 
23. Déjean, F.; Gond, J.-P.; Leca, B. Measuring the unmeasured: An institutional entrepreneur strategy in an emerging industry. Hum. Relat. 2004, 57, 741-764. [CrossRef]

24. Waddock, S. Building a new institutional infrastructure for corporate responsibility. Acad. Manag. Perspect. 2008, 22, 87-108. [CrossRef]

25. Delmas, M.; Blass, V. Measuring corporate environmental performance: The trade-offs of sustainability ratings. Bus. Strateg. Environ. 2010, 19, 217-219. [CrossRef]

26. Ștefănescu, A.; Tănase, G.L. The development of a corporate governance assessment model for the Romanian public sector. Audit Financ. 2016, 14, 1173-1180. [CrossRef]

27. EY Tomorrow's Investment Rules: Global Survey of Institutional Investors on Non-Financial Performance, EYGM Limited. Available online: https://www.eycom.ch/en/Publications/20140502-Tomorrowsinvestment-rules-a-global-survey/download (accessed on 22 September 2017).

28. Albu, N.; Albu, C.; Dumitru, M.; Dumitru, V.F. Plurality or Convergence in Sustainability Reporting Standards? Amfiteatru Econ. 2013, 15, 729-742.

29. Dumitru, M.; Gușe, R.G.; Feleagă, L.; Mangiuc, D.M.; Feldioreanu, A.I. Marketing Communications of Value Creation in Sustainable Organizations. The Practice of Integrated Reports. Amfiteatru Econ. 2015, 17, 955-976.

30. Calu, D.A.; Dumitru, M.; Glăvan, M.E.; Gușe, R.G. (Non)Financial Reporting (A)Symmetries in the Case of Amusement Parks in Europe. Amfiteatru Econ. 2016, 18, 1015-1033.

31. Isaksson, R.; Steimle, U. What does GRI-reporting tell us about corporate sustainability? TQM J. 2009, 21, 168-181. [CrossRef]

32. Doni, F; Gasperini, A.; Pavone, P. Early adopters of integrated reporting: The case of the mining industry in South Africa. Afr. J. Bus. Manag. 2016, 10, 187-208. [CrossRef]

33. Herzig, C.; Schaltegger, S. Corporate Sustainability Reporting. An Overview. In Sustainability Accounting and Reporting, 1st ed.; Schaltegger, S., Bennett, M., Burritt, R., Eds.; Springer: Dordrecht, The Netherlands, 2006; pp. 301-324.

34. Hahn, T.; Figge, F.; Figge, F. Beyond the bounded instrumentality in current corporate sustainability research: Toward an inclusive notion of profitability. J. Bus. Ethics 2011, 104, 325-345. [CrossRef]

35. Rahman, N.; Post, C. Measurement issues in environmental corporate social responsibility (ECSR): Toward a transparent, reliable, and construct valid instrument. J. Bus. Ethics 2012, 105, 307-319. [CrossRef]

36. Singh, R.K.; Murty, H.R.; Gupta, S.K.; Dikshit, A.K. An overview of sustainability assessment methodologies. Ecol. Indic. 2012, 15, 281-299. [CrossRef]

37. Simnett, R.; Huggins, A. Integrated reporting and assurance: Where can research add value? Sustain. Acc. Manag. Policy J. 2015, 6, 29-53. [CrossRef]

38. Reuter, M.; Messner, M. Lobbying on the integrated reporting framework: An analysis of comment letters to the 2011 discussion paper of the IIRC. Acc. Audit. Acc. J. 2015, 2, 365-402. [CrossRef]

39. Dragomir, V.D. The disclosure of industrial greenhouse gas emissions: A critical assessment of corporate sustainability reports. J. Clean. Prod. 2012, 29-30, 222-237. [CrossRef]

40. Eccles, R.; Krzus, M.; Rogers, J.; Serafeim, G. The need for sector-specific materiality and sustainability reporting standards. J. Appl. Corp. Financ. 2012, 24, 8-14. [CrossRef]

41. Nguyen, Q.A.; Hens, L. Environmental performance of the cement industry in Vietnam: The influence of ISO 14001 certification. J. Clean. Prod. 2015, 96, 362-378. [CrossRef]

42. Laxe, F.G.; Bermúdez, F.M.; Palmero, F.M.; Novo-Corti, I. Sustainability and the Spanish port system. Analysis of the relationship between economic and environmental indicators. Mar. Pollut. Bull. 2016, 113, 232-239. [CrossRef] [PubMed]

43. Lucato, W.C.; Costa, E.M.; de Oliveira Neto, G.C. The environmental performance of SMEs in the Brazilian textile industry and the relationship with their financial performance. J. Environ. Manag. 2017, 203, 550-556. [CrossRef]

44. Rowbottom, N.; Locke, J. The emergence of integrated reporting. In Proceedings of the 7th Asia-Pacific Interdisciplinary Research in Accounting Conference, Kobe, Japan, 26-28 July 2013.

45. Global Reporting Initiative \& International Integrated Reporting Council, GRI and IIRC Deepen Cooperation to Shape the Future of Corporate Reporting. 2013. Available online: https: / / www.globalreporting.org/information/news-and-press-center/Pages/GRI-and-IIRC-deepencooperation-to-shape-the-future-of-corporate-reporting.aspx (accessed on 20 January 2017). 
46. European Union Directive as Regards Disclosure of Non-Financial and Diversity Information by Certain Large Undertakings and Groups, 2014/95/EU. 2014. Available online: http://eur-lex.europa.eu/ legalcontent/EN/TXT/PDF/?uri=CELEX:32014L0095\&from=EN/ (accessed on 26 January 2017).

47. La Torre, M.; Sabelfeld, S.; Blomkvist, M.; Tarquinio, L.; Dumay, J. Harmonising non-financial reporting regulation in Europe: Practical forces and projections for future research. Med. Acc. Res. 2018, 26, 598-621. [CrossRef]

48. Carini, C.; Rocca, L.; Veneziani, M.; Teodori, C. Ex-Ante Impact Assessment of Sustainability Information-The Directive 2014/95. Sustainability 2018, 10, 560. [CrossRef]

49. Venturelli, A.; Caputo, F.; Cosma, S.; Leopizzi, R.; Pizzi, S. Directive 2014/95/EU: Are Italian companies already compliant? Sustainability 2017, 9, 1385. [CrossRef]

50. International Integrated Reporting Council, IIRC Pilot Programme Business Network 2013. Available online: http:/ / integratedreporting.org/wp-content/uploads/2013/12/IIRC-PP-Yearbook-2013_PDF4_ PAGES.pdf (accessed on 10 December 2016).

51. Global Reporting Initiative, Reporting Principles and Standard Disclosures-Part I. 2011. Available online: https: / / www.globalreporting.org/resourcelibrary/GRIG4-Part1-Reporting-Principles-and-StandardDisclosures.pdf (accessed on 15 January 2017).

52. IEA, Energy Technology Perspectives 2017. Available online: https://eneken.ieej.or.jp/data/7432.pdf (accessed on 28 November 2018).

53. Helliwell, R.; Tomei, I. Practicing stewardship: EU biofuels policy and certification in the UK and Guatemala. Agric. Hum. Values 2017, 34, 473-484. [CrossRef]

54. REN21. Renewables 2017 Global Status Report; REN21 Secretariat: Paris, France, 2017; pp. 1-302.

55. Sarasa-Maestro, C.J.; Dufo-Lopez, R.; Bernal-Agustín, J.L. Photovoltaic remuneration policies in the European Union. Energy Policy 2013, 55, 317-328. [CrossRef]

56. García-Alvarez, M.T.; Cabeza-García, L.; Soares, I. Assessment of energy policies to promote photovoltaic generation in the European Union. Energy 2018, 151, 864-874. [CrossRef]

57. Falcone, P.M.; Lopolito, A.; Sica, E. The networking dynamics of the Italian biofuel industry in time of crisis: Finding an effective instrument mix for fostering a sustainable energy transition. Energy Policy 2018, 112, 334-348. [CrossRef]

58. Ortega-Izquierdo, M.; del Río, P. Benefits and costs of renewable electricity in Europe. Renew. Sustain. Energy Rev. 2016, 61, 372-383. [CrossRef]

59. Nepal, R.; Jamasb, T.; Tisdell, C.A. On environmental impacts of market-based reforms: Evidence from the European and Central Asian transition economies. Renew. Sustain. Energy Rev. 2017, 73, 44-52. [CrossRef]

60. Scarlat, N.; Dallemand, J.F.; Monforti-Ferrario, F.; Banja, M.; Motola, V. Renewable energy policy framework and bioenergy contribution in the European Union-An overview from National Renewable Energy Action Plans and Progress Reports. Renew. Sustain. Energy Rev. 2015, 51, 969-985. [CrossRef]

61. IEA. Capturing the Multiple Benefits of Energy Efficiency 2014. Available online: https://www.iea. org/publications/freepublications / publication/Multiple_Benefits_of_Energy_Efficiency.pdf (accessed on 28 November 2018).

62. Cucchiella, F.; D’Adamo, I.; Gastaldi, M.; Koh, S.C.L.; Rosa, P. A comparison of environmental and energetic performance of European countries: A sustainability index. Renew. Sustain. Energy Rev. 2017, 78, 401-413. [CrossRef]

63. European Commission Roadmap to a Resource Efficient Europe. COM(2011)571, 2011. Office for Official Publications of the European Communities. Available online: http:/ / eur-lex.europa.eu/legal-content/EN/ TXT/?uri=CELEX:52011DC0571 (accessed on 19 December 2017).

64. Sherman, W.; Diguilio, L. The Second Round Of G3 Reports: Is Triple Bottom Line Reporting Becoming More Comparable? J. Bus. Econ. Res. 2010, 8, 59-77. [CrossRef]

65. Krippendorff, K. Content Analysis: An Introduction to Its Methodology; Sage Publications, Inc.: Thousand Oaks, CA, USA, 1980.

66. Global Reporting Initiative, Sustainability Reporting Guidelines-Version 3.0. 2006. Available online: https:/ / www.globalreporting.org/resourcelibrary/G3-Guidelines-Incl-Technical-Protocol.pdf (accessed on 15 January 2017). 
67. Global Reporting Initiative, Sustainability Reporting Guidelines-Version 3.1. 2011. Available online: https: / / www.globalreporting.org/resourcelibrary/G3.1-Guidelines-Incl-Technical-Protocol.pdf (accessed on 15 January 2017).

68. Global Reporting Initiative, Implementation Manual-Part II. 2011. Available online: https: / / www.globalreporting.org/resourcelibrary/GRIG4-Part2-Implementation-Manual.pdf (accessed on 15 January 2017).

69. Global Reporting Initiative, Consolidated Set of GRI Sustainability Reporting Standards 2016. Available online: https:/ / www.globalreporting.org/standards/gri-standards-download-center/consolidated-setof-gri-standards / (accessed on 15 January 2017).

70. DiMaggio, P.; Powell, W. The iron cage revisited: Institutional isomorphism and collective rationality in organizational fields. Am. Sociol. Rev. 1983, 48, 147-160. [CrossRef]

71. Powell, W.; DiMaggio, P. The New Institutionalism in Organizational Analysis; University of Chicago Press: Chicago, IL, USA, 1997.

72. Dumitru, M.; Dyduch, J.; Gușe, R.G.; Krasodomska, J. Corporate reporting practices in Poland and Romania-An ex-ante study to the new non-financial reporting European Directive. Acc. Eur. 2017, 14, 279-304. [CrossRef]

73. Islam, M.A.; Deegan, C. Media pressures and corporate disclosure of social responsibility performance information: A study of two global clothing and sports retail companies. Acc. Bus. Res. 2010, 40, 131-148. [CrossRef]

74. De Villiers, C.; Alexander, D. The institutionalization of corporate social responsibility reporting. Br. Acc. Rev. 2014, 46, 198-212. [CrossRef]

75. Azapagic, A. Developing a framework for sustainable development indicators for the mining and minerals industry. J. Clean. Prod. 2004, 12, 639-662. [CrossRef]

76. Solvay Annual Integrated Report 2016. Available online: https://www.solvay.com/en/investors/ publications / reports / 2016-annual-report.html (accessed on 11 July 2017).

77. Dragomir, V.D. How do we measure corporate environmental performance? A critical review. J. Clean. Prod. 2018, 196, 1124-1157. [CrossRef]

78. Dragomir, V.D. Environmentally sensitive disclosures and financial performance in a European setting. J. Acc. Organ. Chang. 2010, 6, 359-388. [CrossRef]

79. Holder-Webb, L.; Cohen, J.R.; Nath, L.; Wood, D. The Supply of Corporate Social Responsibility Disclosures Among, U.S. Firms. J. Bus. Ethics 2009, 84, 497-527. [CrossRef]

80. Hahn, R.; Lülfs, R. Legitimizing Negative Aspects in GRI-Oriented Sustainability Reporting: A Qualitative Analysis of Corporate Disclosure Strategies. J. Bus. Ethics 2014, 123, 401-420. [CrossRef]

81. Calu, A.; Negrei, C.; Calu, D.A.; Avram, V. Reporting of Non-Financial Performance Indicators-A Useful Tool for a Sustainable Marketing Strategy. Amfiteatru Econ. 2015, 17, 977-993.

82. Paun, D.; Bray, S.; Yamaguchi, T.; You, S. A Sustainability Performance Assessment Tool: The SPA System. J. Sustain. Educ. 2016, 12, 1-20.

83. James, M.L. The benefits of sustainability and integrated reporting: An investigation of accounting majors' perceptions. J. Legal Ethical Regul. Issues 2015, 18, 1-20.

(C) 2018 by the authors. Licensee MDPI, Basel, Switzerland. This article is an open access article distributed under the terms and conditions of the Creative Commons Attribution (CC BY) license (http://creativecommons.org/licenses/by/4.0/). 